FILIP KACZMAREK

Uniwersytet Ekonomiczny, Poznań

DOI : $10.14746 /$ rie.2016.10.26

\title{
Unia Europejska wobec Światowego Szczytu Humanitarnego
}

W dniach 23-24 maja 2016 r. odbył się w Stambule pierwszy Światowy Szczyt Humanitarny (WHS), zwołany przez sekretarza generalnego Organizacji Narodów Zjednoczonych, a organizowany przez Biuro do spraw Koordynacji Pomocy Humanitarnej (OCHA). Unia Europejska uważa się za jednego z kluczowych podmiotów pomocy humanitarnej w skali globalnej. Argumentem używanym na potwierdzenie tej tezy jest to, że UE jest podmiotem przekazującym największe fundusze na pomoc humanitarną. Argument ten jest uzasadniony jeżeli uwzględnia się sumę zaangażowania finansowego UE i jej państw członkowskich. W roku 2015 Komisja Europejska przeznaczyła na pomoc humanitarną niecałe 2 mld USD, a Wielka Brytania ponad 1,5 mld USD (Funding, 2016, s. 5). Przy założeniu, że wydatki na pomoc humanitarną poniesione przez UE i państwa członkowskie sumują się, można stwierdzić, że UE dostarcza prawie połowę światowego budżetu humanitarnego.

Działania humanitarne UE mają wymiar globalny. Komisja Europejska w 2015 r. zatrudniała 140 ekspertów zajmujących się pomocą humanitarną oraz 320 lokalnych pracowników humanitarnych w 41 państwach (Commission, 2015, s. 2). Pomoc humanitarna należy do zakresu kompetencji dzielonych między Unią a państwami członkowskimi (art. 4 ust. 4 TfUE). Traktat o funkcjonowaniu Unii Europejskiej traktuje pomoc humanitarna jako samodzielną dziedzinę polityki. Art. 14 stwierdza m.in.: „Działania Unii w dziedzinie pomocy humanitarnej są prowadzone zgodnie z zasadami i celami działań zewnętrznych Unii. [...] Działania Unii i Państw Członkowskich wzajemnie się uzupełniają i wzmacniają" (art. 214 ust. 1 TfUE). Wspólne zasady dla wszystkich działań zewnętrznych UE zostały określone w art. 21 Traktatu o Unii Europejskiej, który jako jeden z celów stosunków międzynarodowych wyznacza niesienie „,pomocy narodom, krajom i regionom dotkniętym klęskami żywiołowymi lub katastrofami spowodowanymi przez człowieka" (art. 21 ust. $2 \mathrm{~g}$ TUE). Z badań wynika też, że pomoc humanitarna UE w kontekście współpracy z ONZ jest jednym z tych obszarów, gdzie występuje duża spójność działań Unii i jej państw członkowskich (Starzyk-Sulejewska, 2015, s. 393).

W przypadku samego Szczytu UE uznawała się za jednego z kluczowych uczestników ${ }^{1}$. Szczyt był zatem okazją do zaprezentowania wiodącej roli UE w pomocy humanitarnej. Jakie było stanowisko i oczekiwania UE i jej instytucji wobec Szczytu? Jak UE przygotowywała się do tego wydarzenia? Jaki był wpływ polityczny i merytoryczny UE? I jak UE oceniła sam szczyt i jego rezultaty? W celu odpowiedzi na te

${ }^{1}$ Przedstawicielka Rady, minister obrony Holandii Jeanine Hennis-Plasschaert podczas debaty w Parlamencie Europejskim 10 maja 2016 r. do kluczowych aktorów zaliczyła: ONZ, organizacje humanitarne, instytucje UE i państwa członkowskie (Przygotowania, 2016). 
pytania w niniejszym tekście zostanie przedstawiona analiza przygotowań instytucji UE do Szczytu, udziału przedstawicieli UE i ocen Szczytu dokonanych w UE.

Unia Europejska przygotowywała się do Szczytu długo i kompleksowo. W wypracowaniu stanowiska UE współuczestniczyły wszystkie kluczowe instytucje unijne - Rada, Komisja Europejska i Parlament Europejski. Oczekiwania UE wobec Szczytu były daleko idące i ambitne. Przygotowania do Szczytu stały się jednym z priorytetów prezydencji holenderskiej w Radzie. W programie prezydencji zapisano, że Holandia będzie zabiegać na rzecz tego by głos europejski podczas Szczytu był „silny” (Programme, 2016, s. 14). Minister handlu zagranicznego i współpracy rozwojowej Lilianne Ploumen potwierdziła to na posiedzeniu Komisji Rozwoju Parlamentu Europejskiego 17 lutego 2016 r. (The priorities, 2016). Holandia zwracała szczególną uwagę m.in. na technologiczne innowacje w dziedzinie pomocy humanitarnej oraz na ochronę kobiet i dziewcząt w sytuacjach kryzysowych. Rząd holenderski już w lipcu 2015 r. powołał wysłannika do spraw WHS. Został nim René van $\mathrm{Nes}^{2}$. O tym, że rola wysłannika nie ograniczała się do reprezentowania stanowiska rządu holenderskiego świadczy fakt, że miejscem jego pracy była Bruksela, a nie Haga. Holandia była też gospodarzem pierwszego spotkania negocjatorów tzw. „Wielkiego układu” między darczyńcami a organizacjami humanitarnymi w lutym 2016 r. $^{3}$

Dwa najważniejsze dokumenty Rady w sprawie Szczytu to konkluzje Rady z 10 grudnia 2015 r. na temat przygotowań, a w szczególności konkluzje podjęte przez Radę tuż przed samym Szczytem 12 maja 2016 r. Dokument ten kończył się stwierdzeniem: „Powodzenie Światowego Szczytu Humanitarnego będzie zależeć od terminowego wdrożenia wszystkich zobowiązań zainteresowanych stron. UE i jej państwa członkowskie apelują o stanowcze przywództwo ONZ, by zapewnić obejmujące wszystkich, odpowiedzialne, przejrzyste i sprawne działania następcze. Będziemy składać regularne sprawozdania z realizacji naszych zobowiązać i zachęcać pozostałe zainteresowane strony, by również tak czyniły" (Konkluzje, 2016, s. 8). Rada apelowała też do światowych przywódców by w Stambule zobowiązali się do przestrzegania „humanitarnych zasad człowieczeństwa, neutralności, bezstronności i niezależności oraz na rzecz niedopuszczania do upolitycznienia i instrumentalizacji pomocy humanitarnej" (Konkluzje, 2016, s. 2). Z konkluzji Rady jednoznacznie wynika, że przedstawiciele państw członkowskich zdawali sobie sprawę, jak poważnym problemem jest naruszanie międzynarodowego prawa humanitarnego. Mieli też świadomość, że rozwiązanie tego problemu wykracza poza możliwości samego Szczytu. Dlatego adresują swoje postulaty nie tylko do Szczytu: „Apelujemy do członków Rady Bezpieczeństwa ONZ o niegłosowanie na forum tej Rady przeciw wiarygodnym projektom rezolucji dotyczących terminowych i zdecydowanych działań mających na celu położenie kresu ludobójstwu, zbrodniom przeciwko ludzkości lub zbrodniom wojennym lub zapobieżenie takim zbrodniom" (Konkluzje, 2016, s. 2).

Jednocześnie, obok wymiaru globalnego pomocy humanitarnej, państwa członkowskie UE intensywnie zajmowały się humanitarnym aspektem kryzysu uchodźcze-

${ }^{2}$ Wcześniej pracował w Europejskiej Służbie Działań Zewnętrznych i przedstawicielstwach UE w Tanzanii i Etiopii.

${ }^{3}$ Gospodarzami kolejnych rund negocjacyjnych była Komisja Europejska, Wielka Brytania i Szwecja. 
go. 15 marca 2016 r. Rada przyjęła rozporządzenie w sprawie udzielania nadzwyczajnego wsparcia w ramach Unii. Celem nowych regulacji jest umożliwienie reakcji UE na potrzeby humanitarne spowodowane kryzysem uchodźczym. Nie będzie odbywało się to kosztem zmniejszenia wydatków UE na pomoc humanitarną w krajach trzecich. Środki finansowe będą bowiem pochodziły z linii budżetowych przeznaczonych na politykę wewnętrzną.

Druga kluczowa instytucja UE - Komisja Europejska już we wrześniu 2015 r. ogłosiła Komunikat „W kierunku Światowego Szczytu Humanitarnego: globalne partnerstwo na rzecz skutecznych działań humanitarnych opartych na przyjętych zasadach". Jest to dokument o charakterze konsultacyjnym. Sformułowano w nim 23 zalecenia. Komisja objęła nimi siedem obszarów tematycznych.

- Wartości humanitarne (godność, uczciwość, solidarność, niezależność, respektowanie prawa międzynarodowego).

- Zapewnienie dostępu do pomocy humanitarnej.

- Priorytet dla ochrony osób w ramach działań humanitarnych.

- Globalne partnerstwo w sprawie skuteczności działań humanitarnych.

- Stosowanie zasady pomocniczości.

- Odpowiednie finansowanie.

- Współpraca z partnerami, zajmującymi się działaniami rozwojowymi.

Część z zaleceń Komisji jest ogólna. Do ogólnych można zaliczyć pierwsze zalecenie wymienione w komunikacie: „Szczyt stanowi wyjątkową okazję do odnowienia wspólnych zobowiązań i potwierdzenia naszej wspólnej odpowiedzialności za ochronę życia ludzkiego i udzielanie pomocy humanitarnej. Należy zaapelować o wykorzystanie w tym celu wszystkich możliwych środków czy to politycznych, rozwojowych, czy humanitarnych. Wynikiem szczytu powinno być potwierdzenie wspólnych podstaw: wartości takich jak godność, uczciwość i solidarność; zasad niesienia pomocy humanitarnej; poszanowania zobowiązań wynikających z międzynarodowego prawa humanitarnego oraz zobowiązania do prowadzenia działań humanitarnych niezależnych od sytuacji politycznej" (Komunikat, 2015, s. 4). Przykładem bardziej konkretnego zalecenia są oczekiwana Komisji, dotyczące roli rządów w stosunku do pomocy humanitarnej: „Rządy powinny przede wszystkim zapewnić bezpieczne warunki do prowadzenia działań humanitarnych. Powinny one również zagwarantować odpowiednie podstawy prawne i ramy polityczne ułatwiające dostęp pomocy humanitarnej: a) w odniesieniu do pracowników organizacji humanitarnych: dotyczące przywilejów i immunitetów, wiz i warunków wjazdu, pozwoleń na pracę, swobody przemieszczania się; jak również umożliwiające prowadzenie działań humanitarnych w kontekście środków zwalczania terroryzmu; b) w odniesieniu do sprzętu i towarów: dotyczące wymogów i taryf celnych, podatków i transportu" (Komunikat, 2015, s. 5).

Komisja Europejska dużą wagę przywiązuje do skuteczności działań humanitarnych, co znalazło swój wyraz już w tytule Komunikatu. Zalecenie dotyczące skuteczności jest konkretne: „Społeczność humanitarna powinna opracować kompleksowa tablicę wyników dotyczącą skuteczności pomocy humanitarnej w celu usprawnienia całego cyklu reagowania. Wszystkie podmioty zaangażowane w działania humanitarne powinny wnosić wkład w tę tablicę i z niej korzystać" (Komunikat, 2015, s. 7). Komisja proponuje również, co mogłoby wejść w skład tablicy wyników: 
- repozytorium wspólnych danych na temat potrzeb, zagrożeń, słabych stron i dostępu;

- spis dostępnych zasobów;

- platforma wspólnej analizy ryzyka i koordynacji oceny potrzeb;

- baza danych pozwalająca na śledzenie wszystkich środków finansowych ze wszystkich źródeł oraz podwykonawców, lokalnych partnerów i beneficjentów;

- wspólne wskaźniki jakości;

- wspólne wskaźniki wyników;

- ocena wyników i wpływu;

- badania naukowe (Komunikat, 2015, s. 7-8).

Tego samego dnia, co Komunikat, opublikowano również dokument roboczy służb Komisji, koncentrujący się na politykach i narzędziach mogących usprawnić pomoc humanitarna. Zaliczono do nich indeks zarządzania ryzykiem INFOR, markery jakości, wskaźniki kluczowych wyników, koncentrowanie się na pomocy w środkach pieniężnych (a nie na pomocy rzeczowej), Ochotniczy Korpus Pomocy Humanitarnej, współpracę między pomocą humanitarną i działaniami rozwojowymi w celu wzmacniania odporności oraz system informacji przestrzennej (wykorzystujący źródła satelitarne i lotnicze) i system zarządzania kryzysowego (The Copernicus Emergency Management Service).

Drugi komunikat, stanowiący propozycję dla Szczytu w zakresie kryzysu uchodźczego, Komisja opublikowała 26 kwietnia 2016 r. Komunikat pt. „Godne życie: przejście od uzależnienia od pomocy do samodzielności. Przymusowe wysiedlenie a rozwój" kończyły oczekiwania wobec Szczytu. Komisja uważała, że Szczyt: „zapewni UE i jej państwom członkowskim istotną możliwość nawiązania współpracy z innymi podmiotami, aby zagwarantować podjęcie stosownych działań politycznych na odpowiednio wczesnym etapie oraz aby działać na rzecz wdrażania spójniejszego i bardziej całościowego globalnego podejścia do problematyki przymusowych wysiedleń. Zobowiązanie to powinno opierać się na wspólnym programie strategicznym oraz na ściślejszej współpracy między darczyńcami na szczeblu międzynarodowym, rządami państw przyjmujących, przedstawicielami społeczności lokalnych i społeczeństwa obywatelskiego oraz samymi przesiedleńcami" (Komunikat, 2016, s. 19).

Komisarz Christos Stylianides 15 grudnia 2015 r., podczas debaty w Parlamencie Europejskim podkreślił, że jego „osobistym” priorytetem związanym ze Szczytem jest „zwiększające się naruszenia międzynarodowego prawa humanitarnego" (Przygotowania, 2016). Podobnie wypowiedział się kilka dni przed Szczytem: „Ustanowienie międzynarodowego prawa humanitarnego najważniejszym punktem programu Światowego Szczytu Humanitarnego może przynieść realne zmiany. Ochrona ludności cywilnej i pracowników organizacji humanitarnych oraz zapewnienie dostępu do pomocy humanitarnej nie jest dziś kwestią wyboru, lecz powinności" (Komunikat, 2016, s. 1). W strukturze Komisji jednostką organizacyjną odpowiedzialną merytorycznie za przygotowania do Szczytu była Dyrekcja Generalna ds. Pomocy Humanitarnej i Ochrony Ludności (ECHO). W materiałach publikowanych przez ECHO cel stawiany Szczytowi również był ambitny: „Nadszedł czas, aby wspólnie zmienić model świadczenia pomocy". 


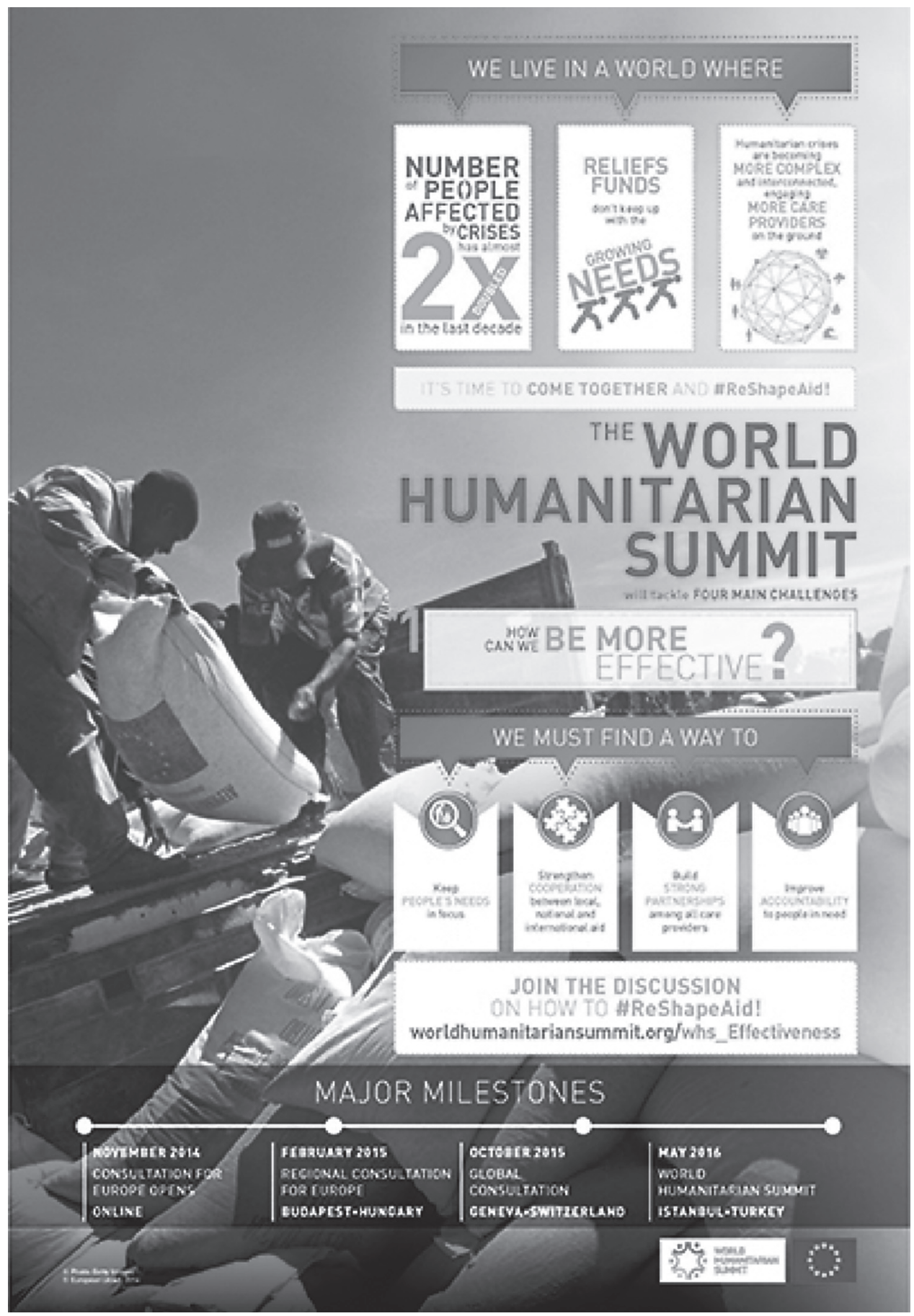

Rys. 1. Infografika ECHO

Źródło: Dyrekcja Generalna ds. Pomocy Humanitarnej i Ochrony Ludności (http://ec.europa.eu/echo/archive-world-humanitarian-summit_en). 
W dzień rozpoczęcia Szczytu, 23 maja opublikowano drugi dokument roboczy służb Komisji. Zatytułowano go: Humanitarian Protection: Improving protection outcomes to reduce risks for people in humanitarian crises. Dokument ten to de facto wytyczne UE w zakresie ochrony ludności.

Równie intensywne były przygotowania kolejnej instytucji UE - Parlamentu Europejskiego. Już w sierpniu 2014 r. w Dyrekcji Generalnej ds. Polityk Zewnętrznych przygotowano analizę pt. Humanitarian aid: crises, trends, challenges. W maju $2015 \mathrm{r}$. na zlecenie Komisji Rozwoju Parlamentu Cristina Churruca Muguruza ${ }^{4}$ opracowała analizę pt. Towards more effective global humanitarian action: How the EU can contribute. W marcu 2016 r. Komisja Rozwoju zorganizowała warsztat pt. The World Humanitarian Summit: Time for action, not for complacency. Do udziału zaproszono przedstawicieli ONZ, Komisji Europejskiej, prezydencji holenderskiej, organizacji pozarządowych i badaczy. Rezultatem warsztatu była pogłębiona analiza pt. WORKSHOP The World Humanitarian Summit 2016 - Time for action, not for complacency.

Jednak najważniejszym elementem formułowania stanowiska Parlamentu Europejskiego wobec Szczytu była rezolucja przyjęta 16 grudnia 2015 r. Parlament Europejski określił w niej swoje oczekiwania wobec Światowego Szczytu Humanitarnego. Posłowie, wiodącej w tej sprawie, Komisji Rozwoju byli podzieleni w stosunku do projektu przygotowanego przez hiszpańskiego socjalistę Enrique Guerrero Salom. Do sprawozdania zgłoszono 128 poprawek. Komisja Rozwoju, a później cały Parlament nie był tak jednomyślny w sprawie stanowiska wobec Szczytu, jak Rada czy Komisja Europejska. W końcowym głosowaniu Komisji Rozwoju za sprawozdaniem głosowało 14 posłów (siedmiu socjalistów, trzech liberałów, dwóch Zielonych, jeden poseł GUE/NGL i jeden poseł EFDD). Przeciw było dwóch posłów EPP i jeden poseł EFDD. Od głosu wstrzymało się sześciu posłów EPP i jeden poseł GUE/NGL (Sprawozdanie, 2015, s. 38).

W Komisji Rozwoju podziały polityczne nie występują często. Co było zatem przyczyną sporu? W tym przypadku była to kwestia aborcji. EPP postanowiła, że jest to dla tej frakcji kwestia kluczowa (key vote). EPP przegrała głosowanie w sprawie aborcji i teoretycznie powinna być przeciw rezolucji. Większość posłów tego ugrupowania w Komisji Rozwoju nie chciała jednak głosować przeciw całej rezolucji - dlatego wstrzymali się od głosu. Dwoje najbardziej konserwatywnych posłów EPP w Komisji Rozwoju ${ }^{5}$, z powodu aborcji, zagłosowało przeciw. Kwestia aborcji pojawiła się również podczas debaty plenarnej i miała wpływ na wynik głosowania w sprawie rezolucji. Poseł Marek Jurek stwierdził: „Laureatka pokojowej nagrody Nobla Matka Teresa z Kalkuty powiedziała kiedyś, że zabijanie nienarodzonych jest największym zagrożeniem dla pokoju na świecie. Warto przypomnieć te słowa w przeddzień naszego głosowania nad dokumentem, który jako jeden z nakazów humanitaryzmu prezentuje nam, zacytuję dosłownie: „dostęp do aborcji”. Na świecie żyje wiele dzieci, którym władze polityczne życzyły, żeby się nigdy nie urodziły, również takich dzieci na tej sali, którym tego życzono. I warto, żebyśmy o tym pamiętali wtedy, kiedy nad tym sprawozdaniem będziemy głosować" (Przygotowania, 2015). Jednak zapis w rezolu-

${ }^{4}$ Institute of Human Rights, University of Deusto, Network of Universities in Humanitarian Action.

${ }^{5}$ Anna Záborská, Joachim Zeller. 
cji, do którego nawiązywał poseł M. Jurek, był znacznie szerszy i bardziej kompleksowy niż słowa ,dostęp do aborcji”.

Parlament Europejski w ust. 21 swej rezolucji: „wzywa do globalnego zaangażowania na rzecz zapewnienia, że kobiety i dziewczęta są bezpieczne od początku każdej sytuacji nadzwyczajnej lub kryzysu poprzez zajęcie się zwiększonym ryzykiem przemocy seksualnej i związanej z płcią, podnoszenie świadomości, zapewnienie ścigania sprawców takich aktów przemocy oraz zapewnienie w sytuacjach kryzysu humanitarnego kobietom i dziewczętom - czego wymaga międzynarodowe prawo humanitarne i co przewidziane jest $\mathrm{w}$ konwencjach genewskich i ich protokołach dodatkowych - dostępu do pełnego zakresu usług w dziedzinie zdrowia seksualnego i reprodukcyjnego, w tym bezpiecznych aborcji [podkreślenie moje], zamiast utrzymywania stanu, który jest równoznaczny z nieludzkim traktowaniem". W głosowaniu nad rezolucją Parlament był podzielony. Grupy EPP i ECR zgłosiły wniosek, by odrębnie głosować słowa „w tym bezpiecznych aborcji”, stanowiące fragment ust. 21. Głosowanie to przegrali, a więc kwestionowane słowa pozostały w tekście rezolucji. W rezultacie za całą rezolucją głosowało 395 posłów, 63 przeciw, a aż 244 wstrzymało się od głosu (Protokót, 2015, s. 43-44).

Parlament w pierwszym punkcie swej rezolucji apelował między innymi o: „realizację wiążących wniosków Rady zawierających konkretne zobowiązania i priorytetowe obszary działania i jednoczesne dążenie do osiągnięcia efektywności operacyjnej, wspólnych standardów jakości, lepszej koordynacji i partnerstwa z nowymi darczyńcami w oparciu o bezstronną politycznie pomoc oraz wspólne zrozumienie i stosowanie zasad humanitarnych człowieczeństwa, neutralności, bezstronności i niezależności, jak również poszanowanie zobowiązań wynikających z międzynarodowego prawa humanitarnego" (ust. 1). Posłowie oczekiwali też, że dokument końcowy Szczytu: „powinien zawierać pięcioletni plan działania na rzecz rozwoju i realizacji podjętych konkretnych zobowiązań politycznych z uwzględnieniem międzyrządowego monitorowania i ram odpowiedzialności, oceny praktyk organizacji i badania skutków, uwzględniającego uczestnictwo odnośnych zainteresowanych stron” (ust. 4). Lista postulatów Parlamentu wobec Szczytu była długa i obejmowała m.in.:

- zobowiązanie do systematycznego, opartego na wynikach i partycypacyjnego podejścia poprzez ustanowienie szczegółowych wskaźników i metodologii pracy (ust. 7);

- instytucjonalizację, lepsze monitorowanie i ocenę ram odpowiedzialności ONZ wobec poszkodowanej ludności (ust. 7);

- odejście od kultury reagowania i przejścia do kultury zapobiegania (ust. 10);

- rozszerzenia konwencji w sprawie uchodźców (ust. 13);

- doprowadzenie do sytuacji, w której środki służące zwalczaniu terroryzmu nie będą podważały ani nie będą utrudniały wysiłków humanitarnych (ust. 25);

- ustanowienie nowego układu dla zaangażowania w państwach niestabilnych i w sytuacjach przedłużającego się kryzysu (ust. 38).

Parlament formułował również postulaty wobec Komisji Europejskiej, Rady i państw członkowskich UE.

Posłowie otrzymali wsparcie merytoryczne od służb wewnętrznych Parlamentu. Biuro Analiz Parlamentu Europejskiego (European Parliamentary Research Service) 
przygotowało dla posłów brifing pt. Funding gap: A challenge for the World Humanitarian Summit (WHS). Przed posiedzeniem przygotowano też skróconą informację na temat Szczytu w sześciu językach: angielskim, francuskim, hiszpańskim niemieckim, polskim i włoskim. Powstały analizy poświęcone kwestiom szczegółowym - informacje o działaniach humanitarnych państw Zatoki Perskiej, Japonii, USA, Rosji, Brazylii, Turcji i Unii Afrykańskiej. Na zlecenie Komisji Praw Kobiet i Równouprawnienia przygotowano pogłębioną analizę pt. Women and Girls in Humanitarian Emergencies. Drugą debatę o przygotowaniach do Szczytu Parlament Europejski przeprowadził w dniu 10 maja 2016 r. Nie wszystkie opinie posłów były zgodne z tym, co prezentowały w swych stanowiskach Rada i Komisja. Poseł Karol Karski, w swym wystapieniu złożonym na piśmie stwierdzał: „Wyrażam nadzieję, że na nadchodzącym szczycie w Stambule uda nam się porozumieć i wypracować takie wspólne priorytety dla międzynarodowej pomocy humanitarnej, które będą uwzględniały interesy poszczególnych państw członkowskich UE" (Przygotowania, 2016). Problem w tym, że postulowane przez posła uwzględnienie interesów poszczególnych państw członkowskich byłoby niezgodne z zasadami udzielania pomocy humanitarnej, promowanymi przez Radę, Komisję i Parlament Europejski.

W ramach przygotowań do Szczytu przeprowadzono też konsultacje na dwóch poziomach. Po pierwsze - europejską część konsultacji w ramach globalnych konsultacji ONZ. Konsultacje te, które współorganizowała Komisja Europejska, odbyły się w dniach 3-4 lutego 2015 r. w Budapeszcie. Były one jednymi z ośmiu konsultacji regionalnych przeprowadzonych na całym świecie. Po drugie - Komisja przeprowadziła konsultacje społeczne. Aktywne było europejskie środowisko naukowe. Dzięki czterem regionalnym konferencjom, zorganizowanym przez Network on Humanitarian Action (NOHA) ${ }^{6}$ powstał raport pt. ONE HUMANITY: Shared Responsibility. A European Perspective.

Na Szczycie UE była reprezentowana przez delegację, w której skład wchodzili wiceprzewodnicząca Komisji Europejskiej Kristalina Georgiewa, komisarz ds. pomocy humanitarnej i zarządzania kryzysowego Christos Stylianides oraz komisarz ds. współpracy międzynarodowej i rozwoju Neven Mimic. W zakresie merytorycznym była to delegacja adekwatna do tematyki Szczytu. Jednak ranga polityczna delegacji nie była zbyt wysoka. Do Stambułu nie pojechał ani przewodniczący Rady, ani przewodniczący Komisji Europejskiej, ani przewodniczący Parlamentu Europejskiego. O tym, że część państw członkowskich UE nie zależało na podniesieniu rangi politycznej Szczytu świadczy ograniczony udział liderów państw członkowskich. Nie był on zbyt liczny, jak na wydarzenie tego typu. Do Stambułu przyjechało czterech prezydentów państw unijnych: Chorwacji - Kolinda Grabar-Kitarović, Cypru - Nikos Anastasiades, Irlandii - Michael D. Higgins, Słowacji - Andrej Kiska oraz dziesięciu szefów rządów: Bułgarii - Bojko Borisow, Finlandii - Juha Sipilä, Grecji - Alexis Tsipras, Holandii - Mark Rutte, Luksemburga - Xavier Bettel, Malty - Joseph Muscat, Niemiec - Angela Merkel, Polski - Beata Szydło, Portugalii - António Costa i Słowenii - Miroslav Cerar.

${ }^{6}$ NOHA jest międzynarodowym konsorcjum skupiającym 12 europejskich uczelni wyższych, którego zadaniem jest profesjonalizacja sektora pomocy humanitarnej poprzez różnego rodzaju aktywności naukowe i dydaktyczne. 
Wkład delegacji Komisji Europejskiej w prace Szczytu był intensywny. Przedstawiciele Komisji zabierali głos na sesji plenarnej, na panelu liderów, podczas 5 z 7 „okragłych stołach” wysokiego szczebla, 7 spośród 15 specjalnych sesji tematycznych, a także podczas 8 z 15 sesji specjalnych i 22 z 132 imprez towarzyszących (World, 2016). W swym wystapieniu plenarnym komisarz C. Stylianides nie formułował oczekiwań wobec Szczytu. Skoncentrował się na zobowiązaniach i deklaracjach UE w zakresie pomocy humanitarnej. Przypomniał wartości i zasady działań humanitarnych, uznawane przez UE. Zidentyfikował grupy o specjalnych potrzebach humanitarnych - kobiety, dzieci, osoby starsze i niepełnosprawne. Podkreślił, że UE zamierza nadal i nieustannie zabiegać o respektowanie międzynarodowego prawa humanitarnego. Deklarował, że UE nikogo nie zostawi bez pomocy, że człowiek będzie w centrum działań humanitarnych, że UE zajmie się złożonymi przyczynami kryzysu uchodźczego. Komisarz zapowiadał też między innymi działanie na rzecz usamodzielnienia przesiedleńców uzależnionych od pomocy, inwestowanie w ograniczanie ryzyka katastrof i w budowanie odporności na katastrofy, bliższą współpracę z partnerami lokalnymi, zapewnieniem synergii pomocy humanitarnej i współpracy rozwojowej. Wyraził nadzieję, że Szczyt będzie punktem zwrotnym we wdrażaniu w życie dla „Planu dla ludzkości”, przygotowanego przez sekretarza generalnego ONZ (Statements, 2016).

W Szczycie uczestniczyła też odrębna delegacja Parlamentu Europejskiego złożona z członków Komisji Rozwoju i Podkomisji Praw Człowieka. W skład delegacji wchodził stały sprawozdawca Komisji Rozwoju do spraw pomocy humanitarnej. Mandat sprawozdawcy obejmuje ochronę budżetu na pomoc humanitarną, monitorowanie unijnych programów pomocy humanitarnej oraz utrzymywanie ścisłych kontaktów ze społecznością działającą w zakresie pomocy humanitarnej. Od 2014 r. funkcję tę pełni Enrique Guerrero Salom (S\&D), który przygotował projekt rezolucji w sprawie Szczytu i przewodniczył delegacji na Szczyt. Drugim uczestnikiem była przewodnicząca Podkomisji Praw Człowieka Elena Valenciano (S\&D). Poseł E. Valenciano była autorką opinii Komisji Spraw Zagranicznych do sprawozdania posła Saloma. Minusem delegacji Parlamentu był fakt, że oboje posłów, pochodziło z tej samej grupy politycznej.

W Szczycie uczestniczyło też wielu innych przedstawicieli europejskich instytucji i organizacji. W Stambule był obecny Europejski Bank Inwestycyjny. Wśród uczestników było wiele europejskich organizacji humanitarnych, w tym trzy polskie organizacje pozarządowe: Polska Akcja Humanitarna, Polska Misja Medyczna i Polskie Centrum Pomocy Międzynarodowej. W Szczycie uczestniczyli też przedstawiciele władz lokalnych. Jednym samorządowcem z Polski był prezydent Gdańska - Paweł Adamowicz. Gospodarzom Szczytu nie udało się uniknąć kłopotu politycznego z udziałem jednego państwa członkowskiego UE. Otóż prezydent Cypru Nikos Anastasiades skrócił swój pobyt na Szczycie i opuścił Turcję wcześniej niż planowano. Uczynił to na znak protestu przeciwko traktowaniu przez gospodarzy przywódcy samozwańczej Tureckiej Republiki Cypru Północnego Mustafy Akinci jak głowy państwa.

Bezpośrednim rezultatem Szczytu są cztery dokumenty: „Komunikat polityczny” (Political Communiqué), ,Wielki układ” (The Grand Bargain-A Shared Commitment to Better Serve People in Need), „Podsumowanie przewodniczącego” (Chair's Summary) i „Zobowiązania do działania” (Commitments to Action). Termin ,zobowiązanie” 
nie oznacza zobowiązania formalnego, prawnie wiążącego zobowiązanego. To zobowiązanie o charakterze politycznym, deklaracja woli. Sygnatariuszami „Zobowiązania do działania" byli: sekretarz generalny ONZ, jego zastępca ds. humanitarnych, Wysoki Komisarz ONZ ds. uchodźców i szefowie oenzetowskich agend - WHO, UNDP, WFP, FAO i UNCF. Dokument uzyskał też wsparcie Banku Światowego i Światowej Organizacji ds. Migracji (IOM). W przypadku „Komunikatu Politycznego” jego status prawny zaznaczono wprost w przypisie: „Niniejszy komunikat nie jest prawnie wiążący i nie ma wpływu na istniejące zobowiązania sygnatariuszy wynikające z prawa międzynarodowego i krajowego. Podpisy poniżej odzwierciedlają raczej wysoki poziom zobowiązań politycznych państw członkowskich" (Political, 2016, s. 1). A i tak pod komunikatem podpisali się przedstawiciele tylko 74 państw (w tym wszystkich państw UE). Z kolei „Wielki układ” został zawarty między 18 darczyńcami (w tym 11 państw $\mathrm{UE}^{7}$ i Komisja Europejska) a 16 organizacjami, zajmującymi się wdrażaniem pomocy humanitarnej ${ }^{8}$. W założeniu ma on zwiększyć wydajność działań humanitarnych.

W Stambule zainaugurowano szereg inicjatyw. Podczas Szczytu podpisano Kartę Osób Niepełnosprawnych w Działaniach Humanitarnych. Wśród sygnatariuszy jest jednak jedynie 14 państw (w tym 6 państw UE) oraz UE jako organizacja regionalna, 12 agend ONZ i prawie 100 organizacji pozarządowych. W tym przypadku w przypisie umieszczono uwage podobna jak w „Komunikacie politycznym”: „Dokument ten wyraża naszą wspólną wolę polityczną i zamierzony kierunek działania. Jednak nie ustanawia on prawnie wiążących zobowiązań państw i innych podmiotów oraz nie wpływa na istniejące zobowiązania sygnatariuszy, wynikające $\mathrm{z}$ innych przepisów międzynarodowych i krajowych" (Charter, 2016, s. 1). UNICEF zainaugurował inicjatywę pod nazwą „Edukacja nie może czekać”, polegającą na utworzeniu funduszu finansującego edukację w sytuacjach kryzysowych. Z kolei FAO zainicjowało Global Partnership for Preparedness (GPP), której celem jest lepsze przygotowanie na kryzysy humanitarne tych krajów, które są obarczone największym ryzykiem. Brak politycznej zgody w sprawie ewentualnego porozumienia o charakterze wiążącym spowodował, że zakres prac Szczytu był bardzo szeroki, ale jednocześnie rozproszony.

Oficjalne oceny Szczytu i jego wyników, dokonane przez instytucje UE są pozytywne. Ocena delegacji Komisji Europejskiej jest optymistyczna, mimo braku realizacji postulatów i oczekiwań sformułowanych przez Komisję przed Szczytem. Wprawdzie w relacji ze Szczytu, które członkowie delegacji przedstawili na posiedzeniu Komisji w dniu 25 maja znalazły się drobne uwagi krytyczne, to jednak oficjalne oświadczenia

${ }^{7}$ Belgia, Bułgaria, Czechy, Dania, Holandia, Luksemburg, Niemcy, Polska, Szwecja, Wielka Brytania i Włochy.

${ }^{8}$ Te organizacje to: Food and Agriculture Organization of the United Nations (FAO), InterAction, International Committee of the Red Cross (ICRC), International Council of Voluntary Agencies (ICVA), International Federation of Red Cross and Red Crescent Societies (IFRC), International Organization for Migration (IOM), Steering Committee for Humanitarian Response (SCHR), United Nations Children's Fund (UNICEF), United Nations Development Programme (UNDP), United Nations Entity for Gender Equality and the Empowerment of Women (UN Women), United Nations High Commissioner for Refugees (UNHCR), United Nations Population Fund (UNFPA), United Nations Office for the Coordination of Humanitarian Affairs (OCHA), United Nations Relief and Works Agency for Palestine Refugees in the Near East (UNRWA), World Bank, World Food Programme (WFP). 
były zdecydowanie pozytywne. Wiceprzewodnicząca K. Georgiewa na posiedzeniu KE zwróciła uwagę, że na Szczycie nie osiagnięto politycznej zgody do zajęcia się przyczynami konfliktów (Minutes, 2016, s. 37). W komunikacie prasowym z 23 maja 2013 r. Komisja stwierdzała: „Pierwszy w historii Światowy Szczyt Humanitarny jest dla społeczności światowej szansą na wzmocnienie i przekształcenie pomocy humanitarnej w najbliższych latach" (Komunikat prasowy, 2016, s. 1). Komisja wyraziła też zadowolenie z przyjęcia „Wielkiego układu”. Jednak większość treści komunikatu jest poświęcona indywidualnym, dodatkowym zobowiązaniom UE. Komisja podjęła takich „zobowiązań” aż 100. Są one w większości powiązane z obszarami tematycznymi, określonymi podczas Szczytu jako „kluczowe zobowiązania”. Do rezultatów Szczytu z perspektywy UE należy zaliczyć również podpisanie Miejskiej Karty Kryzysowej.

Podobnie optymistyczna jest oficjalna ocena Parlamentu Europejskiego. Przewodniczący delegacji Parlamentu Guerrero Salom delikatnie wytknął braki Szczytu, ale ogólna ocena pozostała pozytywna: „Chociaż wyrażamy ubolewanie z powodu braku deklaracji politycznej, dyskusje i zobowiązania dotyczące nowych sposobów finansowania i udzielania pomocy, wzmocnienia zgodności z prawem i odpowiedzialności, są pozytywnymi krokami” (Światowy, 2016). Ocena Szczytu posłanki E. Valenciano była bardziej optymistyczna: „Przyjmujemy z wielkim zadowoleniem fakt, że w wyniku dialogu politycznego wielu darczyńców zobowiązało się do ożywienia zasad humanitarnych i międzynarodowego prawa humanitarnego [...] Był to pierwszy szczyt ONZ zajmujący się wyłącznie pomocą humanitarną z udziałem wielu zainteresowanych stron i był otwarty między innymi dla państw, organizacji pozarządowych i sektora prywatnego. Kilka podpisanych tam dokumentów, przede wszystkim Wielki Pakt, a także zobowiązania do działania, są częścią nowego modelu pracy, który umieszcza osoby dotknięte przez konflikt i katastrofy w centrum planowania i podejmowania decyzji” (Światowy, 2016).

Bardziej krytycznie do osiagnięć Szczytu podchodzą niektóre europejskie organizacje pozarządowe. Krytyka ta jest formułowana z dwóch zupełnie odmiennych pozycji. Pierwszą konstruują organizacje, według których w zakresie pomocy humanitarnej robi się „za mało”. Amnesty International uważa na przykład, że „Jeśli przywódcy państw w zdecydowany sposób nie poruszą kwestii powszechnego lekceważenia prawa międzynarodowego, przez co miliony ludzi zmuszone są do opuszczenia swoich domów, wszelkie kroki podjęte w celu poprawy systemu pomocy humanitarnej nie będą w stanie stawić czoła przyczynom kryzysu" (Światowy Szczyt, 2016). Znana organizacja „Lekarze bez granic” (MSF) była jeszcze bardziej krytyczna i odwołała udział swych przedstawicieli w Szczycie. W oświadczeniu z 5 maja organizacja stwierdzała: „Straciliśmy już nadzieję, że szczyt zajmie się słabymi aspektami niesienia pomocy i reagowania kryzysowego, zwłaszcza w obszarach konfliktu lub podczas epidemii” (MSF to pull, 2016). Kluczowym argumentem MSF był fakt, że „Szczyt nie wzmocni zobowiązań państw na rzecz zachowania i wdrażania podpisanych umów w sprawie pomocy humanitarnej i uchodźców" (MSF to pull, 2016). Tuż przed Szczytem, 20 maja MSF opublikowała własny raport pod znamiennym tytułem Emergency Now: A call for action beyond summits. Organizacja przeciwstawiała się w nim bliższemu powiązaniu pomocy humanitarnej ze współpracą rozwojową. MSF uważa, że dziedziny te mają ,fundamentalnie” różne cele i metody działania. W dokumentach przygo- 
towanych przed Szczytem „Lekarze bez granic” dostrzegają zasadniczą sprzeczność. Polega ona, zdaniem organizacji, na potwierdzeniu dotychczasowych zasad pomocy humanitarnej (w tym niezależności) i jednoczesnym proponowaniu konwergencji między pomocą humanitarną i współpracą rozwojową (Emergency, 2016, s. 2). W raporcie bardzo wyraźnie podkreślono, że pomoc humanitarna nie zajmuje się przyczynami kryzysów, co z kolei było mocno akcentowane przez UE. MSF krytykuje też Unię za jej politykę wobec uchodźców: „Obecnie nie ma możliwości wnioskowania o azyl w UE bez podjęcia niebezpiecznej podróży" (Emergency, 2016, s. 4).

$\mathrm{Na}$ drugiej stronie osi sporu jest grupa organizacji, które uważają, że pomoc humanitarna, w szczególności w kontekście kryzysu uchodźczego, idzie „za daleko”. Odredakcyjny tytuł informacji na temat Szczytu umieszczony na internetowej witrynie inicjatywy „Nie dla islamizacji Europy” brzmiał: „Nie zamkniemy drzwi przed uchodźcami. Absurdalny szczyt humanitarny ONZ w Stambule" (Nie zamkniemy, 2016). A portal internetowy, samookreślający się jako „poświęcony”, fronda.pl był jeszcze bardziej radykalny. Tekst o Szczycie zatytułował „ONZ chce podatku na aborcje, antykoncepcje i dewiacje!" (ONZ chce, 2016). Istotą negatywnej oceny tych organizacji jest opisany wyżej spór o „dostęp do bezpiecznych aborcji”. Część europejskiej prawicy nie akceptuje ,dostępu do aborcji” ani jako elementu zdrowia reprodukcyjnego, ani jako uprawnienia wynikającego z prawa humanitarnego.

Oczekiwania UE wobec pierwszego Światowego Szczytu Humanitarnego były duże i nie zostały zrealizowane, a mimo to Szczyt został oficjalnie uznany za udany. Polityczną przyczyną tej rozbieżności może być ostrożność instytucji unijnych przed kolejnym szczytem globalnym. Na wrzesień 2016 r. zaplanowano szczyt, który z perspektywy bieżącej sytuacji w UE jest politycznie ważniejszy niż pomoc humanitarna. Będzie to szczyt dotyczący przepływu migrantów i uchodźców. A stanowisko Komisji Europejskiej o globalnym aspekcie migracji i kwestii uchodźców jest jasne: „Chociaż UE jest zobowiązana uczestniczyć w pomocy osobom przesiedlonym wyraźnie potrzebującym ochrony międzynarodowej, przesiedlenie uchodźców, w szczególności osób przesiedlonych w wyniku konfliktu syryjskiego, stanowi obszar wspólnej odpowiedzialności wspólnoty międzynarodowej. Międzynarodowi partnerzy UE muszą wziąć na siebie część odpowiedzialności. UE powinna wykorzystać swoją pozycję polityczną w celu uzyskania większego wsparcia ze strony partnerów w tworzeniu bardziej sprawiedliwego systemu przesiedleń" (Komunikat [385], 2016, s. 14). Komisja szczerze zresztą zwraca uwagę, że Szczyt pozwolił ,skierować uwagę na wspólną odpowiedzialność społeczności międzynarodowej” (Komunikat [385], 2016, s. 14). I to wydaje się być kluczowym przesłaniem unijnych instytucji wobec Światowego Szczytu Humanitarnego - próba podzielenia się odpowiedzialnością za pomoc humanitarną. Próba ta okazała się nieskuteczna.

\section{Bibliografia}

Charter on Inclusion of Persons with Disabilities in Humanitarian Action, http://humanitariandisabilitycharter.org/, 18.06.2016.

Commission Staff Working Document Accompanying the document Communication from the Commission to the European Parliament and the Council: Towards the World Humanitarian Sum- 
mit: A global partnership for principled and effective humanitarian action, SWD (2015) 166 final.

Emergency now: A call for action beyond summits, http://www.msf.org/en/article/emergency-nowcall-action-beyond-summits, 17.06.2016.

Funding gap: A challenge for the World Humanitarian Summit (WHS) (2016), European Parliamentary Research Service, http://www.europarl.europa.eu/RegData/etudes/BRIE/2016/582030/ EPRS_BRI(2016)582030_EN.pdf, 8.06.2016.

Komunikat Komisji do Parlamentu Europejskiego, Rady, Europejskiego Komitetu EkonomicznoSpołecznego i Komitetu Regionów „, Godne życie: przejście od uzależnienia od pomocy do samodzielności. Przymusowe wysiedlenie a rozwój”, COM (2016) 234.

Komunikat Komisji do Parlamentu Europejskiego i Rady „,W kierunku Światowego Szczytu Humanitarnego: globalne partnerstwo na rzecz skutecznych działań humanitarnych opartych na przyjętych zasadach”, COM (2015) 419.

Komunikat Komisji do Parlamentu Europejskiego, Rady Europejskiej, Rady i Europejskiego Ban$k u$ Inwestycyjnego $w$ sprawie ustanowienia nowych ram partnerstwa z państwami trzecimi w ramach Europejskiego programu w zakresie migracji, COM (2016) 385.

Komunikat prasowy „Unia Europejska wspóttworzy nowe oblicze pomocy międzynarodowej na Światowym Szczycie Humanitarnym”, 20 maja 2016, IP/16/1829.

Komunikat prasowy , Unia Europejska zobowiazuje się do działania na Światowym Szczycie Humanitarnym", 23 maja 2016, IP/16/1847.

Konkluzje Rady i przedstawicieli rzqdów państw czlonkowskich zebranych w Radzie w sprawie Światowego Szczytu Humanitarnego z 12 maja 2016 r., Dok. 8850/16.

Minutes of the 2170th meeting of the Commission held in Brussels, PV(2016) 2170 final.

MSF to pull out of World Humanitarian Summit, http://www.msf.org/en/article/msf-pull-out-worldhumanitarian-summit, 17.06.2016.

„Nie zamkniemy drzwi przed uchodźcami”. Absurdalny szczyt humanitarny ONZ w Stambule, http://ndie.pl/zamkniemy-drzwi-uchodzcami-absurdalny-szczyt-humanitarny-onz-stambule, 17.06.2016.

One Humanity: Shared Responsibility. A European Perspective (2016), Network on Humanitarian Action (NOHA), Brussels.

ONZ chce podatku na aborcje, antykoncepcje i dewiacje!, http://www.fronda.pl/a/onz-chce-podatkuna-aborcje-antykoncepcje-i-dewiacje,65626.html, 17.06.2016.

Political Communique for the World Humanitarian Summit, http://ec.europa.eu/echo/partnerships/ european-and-international-cooperation/world-humanitarian-summit_en, 15.06.2016.

Proces przygotowań do Światowego Szczytu Humanitarnego - Konkluzje Rady (10 grudnia 2015 r.), Dok. 15232/15.

Programme of the Netherlands Presidency of the Council of the European Union (2016), Ministry of Foreign Affairs, The Hague.

Protokót. 16.12.2015. Wyniki głosowań imiennych-Załacznik, PE573.976.

Przygotowania do Światowego Szczytu Humanitarnego (debata), 10 maja 2016 r., http://www. europarl.europa.eu/sides/getDoc.do?pubRef=-//EP//TEXT+CRE+20160510+ITEM011+DOC $+\mathrm{XML}+\mathrm{V} 0 / / \mathrm{PL} \&$ language $=\mathrm{PL}$, 15.06.2016.

Przygotowania do Światowego Szczytu Humanitarnego: wyzwania i szanse w zakresie pomocy humanitarnej (debata), 15 grudnia 2015 r., http://www.europarl.europa.eu/sides/getDoc.do?type$=$ CRE\&reference $=20151215 \&$ secondRef $=$ ITEM-013\&language $=$ PL\&ring $=$ A8-2015-0332, 15.06.2016.

Rezolucja Parlamentu Europejskiegoz dnia 16 grudnia 2015 r. wsprawieprzygotowańdo Światowego Szczytu Humanitarnego: wyzwania i szanse w zakresie pomocy humanitarnej, P8_TA(2015)0459. 
Sprawozdanie w sprawie przygotowań do Światowego Szczytu Humanitarnego: wyzwania i szanse w zakresie pomocy humanitarnej (2015/2051(INI)), Komisja Rozwoju, Parlament Europejski, PE551.888v02-00.

Statements on behalf of the EU and Member States during the World Humanitarian Summit, http://ec.europa.eu/echo/partnerships/european-and-international-cooperation/worldhumanitarian-summit/statements_en, 17.06.2016.

Starzyk-Sulejewska J. (2015), Stosunki Unii Europejskiej z Organizacja Narodów Zjednoczonych. Podstawy prawne i instytucjonalne oraz wybrane dziedziny wspótpracy, Wydawnictwo Naukowe Scholar, Warszawa.

Światowy Szczyt Humanitarny, https://amnesty.org.pl/swiatowy-szczyt-humanitarny/, 18.06.2016.

Światowy Szczyt Humanitarny: Pierwszy krok w kierunku nowej globalnej akcji na rzecz pomocy humanitarnej, http://www.socialistsanddemocrats.eu/pl/newsroom/world-humanitarian-summit-first-step-towards-new-global-humanitarian-aid-action, 18.06.2016.

The priorities of the Dutch Presidency of the EU Council of Ministers, http://www.europarl.europa. eu/sides/getDoc.do?type=IM-PRESS\&reference=20160126IPR11553\&language $=$ PL\&format=XML, 17.06.2016.

Towards more effective global humanitarian action: How the EU can contribute (2015), DirectorateGeneral for External Policies. Policy Department, [Brussels].

Workshop The World Humanitarian Summit 2016 - Time for action, not for complacency (2016), Directorate-General for External Policies. Policy Department, [Brussels].

World Humanitarian Summit, http://ec.europa.eu/echo/partnerships/european-and-internationalcooperation/world-humanitarian-summit_en, 17.06.2016.

\section{Streszczenie}

W dniach 23-24 maja 2016 r. odbył się w Stambule pierwszy Światowy Szczyt Humanitarny (WHS), zwołany przez sekretarza generalnego Organizacji Narodów Zjednoczonych, a organizowany przez Biuro do spraw Koordynacji Pomocy Humanitarnej (OCHA). Unia Europejska uważa się za jednego z kluczowych podmiotów pomocy humanitarnej w skali globalnej. Działania humanitarne UE rzeczywiście mają wymiar globalny. W przypadku pomocy humanitarnej występuje też duża spójność działań Unii i jej państw członkowskich. W przypadku samego Szczytu UE uznawała się za jednego z najważniejszych uczestników. Szczyt był zatem okazją do zaprezentowania wiodącej roli UE w pomocy humanitarnej. Jakie było stanowisko i oczekiwania UE i jej instytucji wobec Szczytu? Jak UE przygotowywała się do tego wydarzenia? Jaki był wpływ polityczny i merytoryczny UE? I jak UE oceniła sam szczyt i jego rezultaty? W celu odpowiedzi na te pytania autor przeprowadza analizę przygotowań instytucji UE do Szczytu, udziału przedstawicieli UE i ocen Szczytu dokonanych w UE. Oczekiwania UE wobec pierwszego Światowego Szczytu Humanitarnego były duże i nie zostały zrealizowane, a mimo to Szczyt został oficjalnie uznany za udany.

Słowa kluczowe: Światowy Szczyt Humanitarny, Unia Europejska, ONZ, pomoc humanitarna

\section{The European Union's position on the Global Humanitarian Summit}

\section{Summary}

The first World Humanitarian Summit (WHS) was held in Istanbul on 23-24 May 2016. WHS was convened by the Secretary General of the United Nations, and organized by the Of- 
fice for the Coordination of Humanitarian Affairs (OCHA). The European Union is considered to be one of the key actors of humanitarian aid on a global scale. EU humanitarian action actually have a global dimension. In the sphere of humanitarian aid there is also a large coherence of the activities of the Union and its Member States. The summit was a showcase for the leading role of the EU in humanitarian aid. What was the position and expectations of the EU and its institutions to the summit? As the EU prepared for this event? What was the impact of the EU? In order to answer these questions, the author analyzes the preparations for the Summit of the EU institutions, the participation of representatives of the EU and assessments made in the EU. Expectations of the EU to the WHS were large and have not been realized, yet the Summit was officially recognized as successful.

Key words: World Humanitarian Summit, The European Union, United Nations, humanitarian aid 
